Article

\title{
One-Pot Synthesis of (+)-Nootkatone via Dark Singlet Oxygenation of Valencene: The Triple Role of the Amphiphilic Molybdate Catalyst
}

\author{
Bing Hong ${ }^{1}$, Raphaël Lebeuf ${ }^{1}$, Stéphanie Delbaere ${ }^{2}$, Paul L. Alsters ${ }^{3}$ \\ and Véronique Nardello-Rataj ${ }^{1, *}$ \\ 1 Université Lille, CNRS, Centrale Lille, ENSCL, Université Artois, UMR 8181-UCCS-Unité de Catalyse et \\ Chimie du Solide, F-59000 Lille, France; bing.hong@solvay.com (B.H.); lebeufraphael@hotmail.com (R.L.) \\ 2 Université Lille, UDSL, CNRS UMR 8516, F-59006 Lille, France; stephanie.delbaere@univ-lille2.fr \\ 3 DSM ChemTech R\&D B.V., Innovative Synthesis, P.O. Box 18, 6160 MD Geleen, The Netherlands; \\ paul.alsters@dsm.com \\ * Correspondence: veronique.rataj@univ-lille1.fr; Tel.: +33-320-33-6369
}

Academic Editor: Keith Hohn

Received: 16 September 2016; Accepted: 18 November 2016; Published: 26 November 2016

\begin{abstract}
Efficient one-pot catalytic synthesis of (+)-nootkatone was performed from (+)-valencene using only hydrogen peroxide and amphiphilic molybdate ions. The process required no solvent and proceeded in three cascade reactions: (i) singlet oxygenation of valencene according to the ene reaction; (ii) Schenck rearrangement of one hydroperoxide into the secondary $\beta$-hydroperoxide; and (iii) dehydration of the hydroperoxide into the desired (+)-nootkatone. The solvent effect on the hydroperoxide rearrangement is herein discussed. The amphiphilic dimethyldioctyl ammonium molybdate, which is also a balanced surfactant, played a triple role in this process, as molybdate ions catalyzed at both Step 1 and Step 3 and it allowed the rapid formation of a three-phase microemulsion system that highly facilitates product recovery. Preparative synthesis of the high added value (+)-nootkatone was thus performed at room temperature with an isolated yield of $46.5 \%$. This is also the first example of a conversion of allylic hydroperoxides into ketones catalyzed by molybdate ions.
\end{abstract}

Keywords: (+)-valencene; (+)-nootkatone; molybdate ions; hydrogen peroxide; singlet oxygen; microemulsion

\section{Introduction}

(+)-Nootkatone (Figure 1), a sesquiterpene firstly isolated from the heartwood of Alaskan yellow cedar and present in citrus species, is a sought after molecule widely used in flavor and cosmetic fields thanks to its unique grapefruit odor and low perception threshold [1-3]. It is allowed as a food additive at a $0.5 \mathrm{mg} / \mathrm{Kg}$ concentration level by the European Food Safety authority [4] and listed as an authorized flavor for food in the European Regulations. Moreover, recent research has revealed its impressive repellent activity, making it an interesting additive in insecticides against such various insects as termites or ticks [5,6]. The trace amount of (+)-nootkatone in plant sources results in the high price of this flavor and fragrance compound, which is extracted from natural plants in an industrial demand that cannot be met. Accordingly, several chemical synthetic approaches have been developed since the exact structure is known. However, the early synthetic strategies via the Robinson annulation with cyclohexanone derivatives [7-11], the Diels-Alder reaction between the cyclohexa-1,4-diene derivatives and appropriate dienophiles [12,13], cyclopentenone annulation and ring enlargement [14], intramolecular Sakurai reaction [15], and more recently the Diels-Alder/Aldol tandem reaction [16] suffer from a poor control of the configuration of the methyl groups at the C5 and C6 positions as well as the isopropenyl group at C8 position, which generally provide racemic 
$( \pm)$-nootkatone or diastereomers thereof. Different from (+)-nootkatone, $(-)$-nootkatone has a spicy and woody flavor, making it less useful. The synthesis of enantiopure (+)-nootkatone was firstly reported by Yoshikoshi's group from (-)- $\beta$-pinene in an 11\% 14\% overall yield via the acid catalyzed cyclobutane cleavage-Aldol cyclization tandem reaction as a key step $[17,18]$ and was improved by Laine et al. via the stereoselective Grignard/anionic oxy-Cope reaction, giving an overall yield up to $33 \%$ [19]. However, the lengthy reaction procedure, the toxic solvent used, the strict reaction conditions, the tedious work-up, and the low overall yield make the total synthesis of (+)-nootkatone not the best choice from an economic and ecological point of view.

Alternatively, (+)-nootkatone can be prepared by the allylic oxidation of the parent hydrocarbon, (+)-valencene (Figure 1), which is readily obtained from Valencia orange and successfully fermented with biotechnology by Allylix and Isobionics [20]. The oxidation of (+)-valencene with the carcinogenic tert-butyl chromate or sodium dichromate was reported by Hunter et al. [21] and Shaffer et al. [22]. Tert-butyl peracetate was also used for allylic oxidation of valencene, but additional chromic acid was required for the oxidation of intermediate nootkatol [23]. One-pot catalytic conversion of $(+)$-valencene into $(+)$-nootkatone has been realized with tert-butyl hydroperoxide in combination with silica-supported $\mathrm{Co}(\mathrm{OAc})_{2}, \mathrm{Cu}(\mathrm{OAc})_{2}$, or $\mathrm{V}(\mathrm{OAc})_{2}$ catalysts [24]. Chlorite-based oxidations have also been reported [25]. Nevertheless, the explosive, corrosive, and/or toxic properties of the systems mentioned above call for greener and more effective methods for preparing (+)-nootkatone from $(+)$-valencene. Recently, Guerra et al. [26] have reported on the allylic oxidation of $(+)$-valencene with tert-butyl hydroperoxide using a copper-aluminum mixed oxide as a catalyst in the presence of L-proline. They obtained (+)-nootkatone with a yield of $40 \%$. On the other hand, various biocatalysts, such as G. pentaphyllum cultures, green algae Chlorella species, fungi Bothryosphaeria dothidea, the lyophilisate of edible mushroom Pleurotus sapidus, and several bacterial cytochrome P450 enzymes have also been studied for this transformation [27-35]. However, the costly culture conditions, the low conversion rate and yield, the inhibition of enzymes by products, and the presence of various by-products still hamper the industrial preparation of (+)-nootkatone via biocatalysts. Chemo- or biocatalytic methods based on radical chain oxidations with oxygen are more cost-efficient, but may suffer from poor process robustness, while still requiring toxic metal chemocatalysts and large, sub-stoichiometric amounts of unstable organic mediators that cannot be recycled [36,37]. It is, however, noteworthy that (+)-nootkatone synthesized from (+)-valencene could be claimed as "natural" only if all starting materials can be found in nature, which concerns only the enzymatic processes.

We report herein two one-pot syntheses of (+)-nootkatone from (+)-valencene. Both methods involve singlet oxygen $\left({ }^{1} \mathrm{O}_{2},{ }^{1} \Delta_{\mathrm{g}}\right)$ as the oxidant and molybdate ions as a catalyst. The one-pot process comprises three cascade reactions starting from the singlet oxygenation of valencene, which can be either photochemical or chemical, followed by a Schenck rearrangement and ended with the transformation of the allylic hydroperoxide intermediate into the desired nootkatone, also catalyzed by molybdate ions. These cascade reactions describe for the first time the allylic oxidation of cyclic alkenes to ketones catalyzed by molybdate ions.

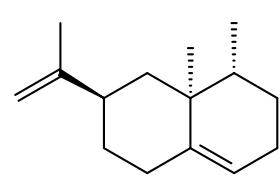

(+)-valencene, 1<smiles>C=C(C)C1CCC2=CC(=O)CC[C@H]2C1</smiles>

(+)-nootkatone, 5

Figure 1. Structure of (+)-valencene and (+)-nootkatone.

\section{Results and Discussion}

Singlet oxygen, ${ }^{1} \mathrm{O}_{2}\left({ }^{1} \Delta_{\mathrm{g}}\right)$, readily reacts with the trisubstituted double bond of (+)-valencene, according to the ene reaction providing selectively two regioisomers. The photooxidation 
of (+)-valencene into hydroperoxides by photochemically generated ${ }^{1} \mathrm{O}_{2}$ has already been reported $[22,38,39]$. The reactions were typically carried out in a methanol/benzene (1:1) mixture in the presence of rose Bengal. These conditions provide mainly a tertiary allylic $\beta$-hydroperoxide $(\approx 70 \%-80 \%)$, which spontaneously rearranges at room temperature into a secondary allylic $\beta$-hydroperoxide $(\approx 60 \%)$ according to the Schenck rearrangement [38-40]. The other secondary hydroperoxide ( $\approx 15 \%-20 \%$ ) formed as a minor product is stable. Davies and Davison reported that these hydroperoxides can also be obtained with ground state oxygen through another mechanism, giving mainly the secondary $\beta$-hydroperoxide in a first step [38]. More recently, Jensen et al. reported the formation of nootkatone by autoxidation of valencene in microfluidic system under solvent-free and catalyst-free conditions [41]. The only work describing the conversion of the secondary $\beta$-hydroperoxide into nootkatone was reported by Ohloff in the presence of copper (I) ions [39].

In a first reference experiment, we carried out the photooxidation of $(+)$-valencene $\mathbf{1}$ in the presence of rose Bengal in methanol. The two expected hydroperoxides $2(71 \%)$ and $3(17 \%)$ were obtained as depicted in Figure 2. Some minor other side products resulting from a reaction of ${ }^{1} \mathrm{O}_{2}$ with the exo-cyclic double bond were also observed.

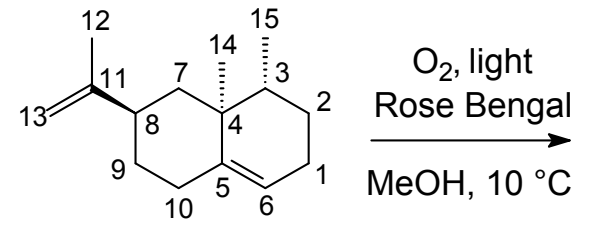

1<smiles>C=C(C)C1CCC2(O)C3CCC(CC3)C2C1</smiles>

2<smiles>C=C(C)C1CC=C2C(O)CCC[C@H]2C1</smiles>

3

Figure 2. Photooxidation of (+)-valencene in methanol.

The selectivity for $\mathbf{2}$ can be accounted for by steric effect as already reported for molecules of a similar structure, such as cholesterol and naphthalenyl derivatives [42,43]. Indeed, the attack of ${ }^{1} \mathrm{O}_{2}$ from the $\alpha$-face is sterically hindered by the two methyl groups, and the axial hydrogen on $\mathrm{C} 10$ is prevented from ene reaction; meanwhile, the equatorial hydrogen is less accessible than the axial hydrogen atoms on $\mathrm{C} 1$. Thus, the $\beta$-isomer of $\mathbf{2}$ is the main product. While the ene reaction is relatively independent of the solvent nature, the conversion of hydroperoxide 2 into hydroperoxide 4 is closely related to the type of solvent. Indeed, in methanol, hydroperoxide $\mathbf{2}$ was stable, and almost no rearrangement product was obtained beyond one month. On the other hand, in a non-protic solvent such as toluene, the Schenck rearrangement of 2 into 4 was able to reach up to $>99 \%$ in two days at room temperature and only in $5 \mathrm{~h}$ at $40^{\circ} \mathrm{C}$ (Figure 3). Several other solvents were then investigated at room temperature. The conversions of $\mathbf{2}$ into 4 are reported in Table 1. It is noteworthy that hydroperoxide 3 does not rearrange.<smiles>C=C(C)C1CCC2(O)C3CCC(C)C(C1)C32O</smiles>

2

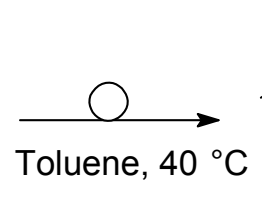

(1)

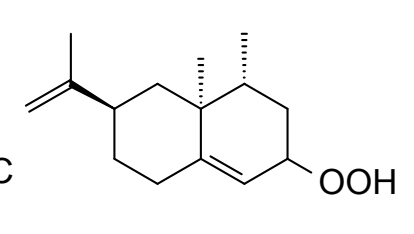

4

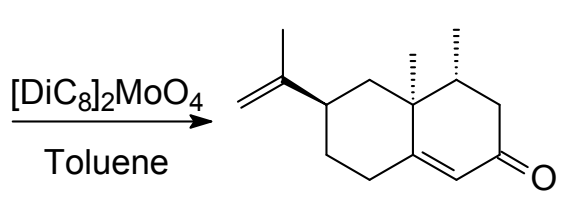

5

Figure 3. Schenck rearrangement of hydroperoxide 2 into hydroperoxide 4 followed by conversion of hydroperoxide 4 into nootkatone 5 catalyzed by molybdate ions in toluene. 
Table 1. Conversion of hydroperoxide 2 into hydroperoxide 4 determined by ${ }^{1} \mathrm{H}$ NMR after $48 \mathrm{~h}$ in various solvents at room temperature using an internal standard (see Supporting Information Figures S11-S13).

\begin{tabular}{cc}
\hline Solvents & Conversion of $\mathbf{2}$ into $\mathbf{4}(\mathbf{\%})$ \\
\hline MeOH & $<5$ \\
Acetone & 55 \\
Acetonitrile & 66 \\
Chloroform & 89 \\
Toluene & $>95$ \\
\hline
\end{tabular}

The kinetics of the Schenck rearrangement reaction is greatly affected by the solvent $[40,44]$. As shown in Table 1, toluene gave the highest rearrangement rate in hydroperoxide 2 . As previously reported, the hydroperoxide dimer combined by hydrogen bonding showed much lower activity than the free hydroperoxide [45,46]. The higher stability of hydroperoxide 2 in methanol can be explained by the hydrogen bond formation between the solvent molecule and the hydroperoxide function, which suppresses the rearrangement.

The dehydration of allylic hydroperoxides into the corresponding enone catalyzed by Lewis acids such as $\mathrm{Cu}^{2+}, \mathrm{Co}^{2+}, \mathrm{Mn}^{2+}$, and $\mathrm{Zr}^{4+}$ has already been reported [47-49]. In this mechanism, the coordination of the metal with the peroxide has been considered to weaken the $\mathrm{O}-\mathrm{O}$ bond and, accordingly, facilitates the dehydration. During our investigations, we found that molybdate ions were also able to catalyze the dehydration of 4 , yielding the desired (+)-nootkatone 5 (see Figure 3). The reaction was investigated in toluene with the amphiphilic bis(dimethyldioctyl)ammonium molybdate abbreviated as $\left[\mathrm{DiC}_{8}\right]_{2}\left[\mathrm{MoO}_{4}\right]$. Figure 4 shows the conversion of hydroperoxide 4 into $(+)$-nootkatone 5 as a function of time for stoichiometric and catalytic amounts of molybdate salt.

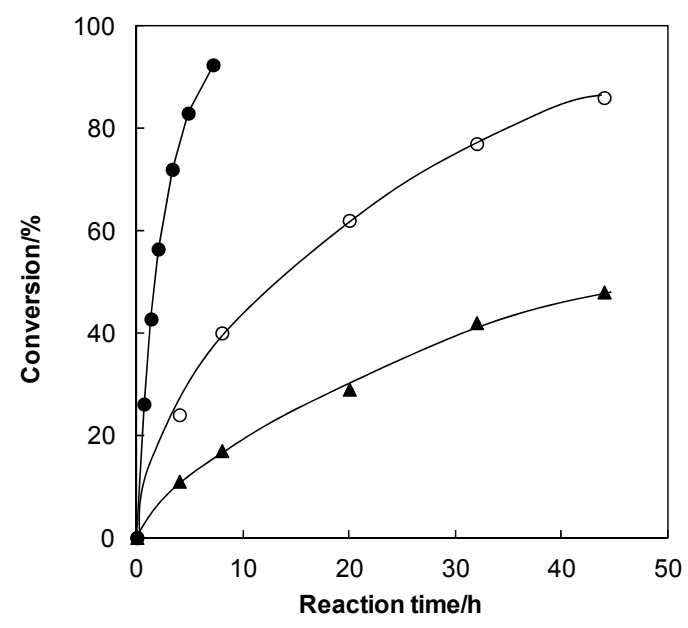

Figure 4. Kinetics of hydroperoxide 4 conversion into nootkatone 5 catalyzed with $\left[\mathrm{DiC}_{8}\right]_{2} \mathrm{MoO}_{4}$. - 0.2 equiv $T=50^{\circ} \mathrm{C} ; \bigcirc 1$ equiv $T=25^{\circ} \mathrm{C} ; \boldsymbol{\Delta} 0.2$ equiv $\mathrm{T}=25^{\circ} \mathrm{C}$.

While the reaction with 0.2 equiv molybdate at $25^{\circ} \mathrm{C}$ is quite slow compared to stoichiometric amounts of molybdate, it is remarkably increased at $50{ }^{\circ} \mathrm{C}$, suggesting a catalytic process. This temperature has been chosen as a good compromise between increasing the reaction rate and avoiding possible thermal degradation of the hydroperoxide intermediates. A possible catalytic cycle is proposed in Figure 5. The coordination of hydroperoxide to the molybdate anion and the proton transfer generates the active species $\mathbf{B}$. The $\alpha$-hydrogen of alkylperoxy ligand is abstracted via a six-membered transition state by the oxygen anion of molybdate, which affords the enone product, and the molybdate is regenerated by dehydration of intermediate species C. A similar six-membered 
ring transition state has been proposed for the tungstate catalyzed alcohol oxidation by $\mathrm{H}_{2} \mathrm{O}_{2}$ [50]. The $\alpha$-hydrogen abstraction of alkyl peroxy ligand was considered as the rate-determining step, which was also supported by the experiment. The yellow solution obtained just after the addition of $\left[\mathrm{DiC}_{8}\right]_{2} \mathrm{MoO}_{4}$ to the hydroperoxide 4 toluene solution confirms the complex formation. Moreover, the complex formation was also confirmed by the ${ }^{1} \mathrm{H}$ NMR analysis, where $\alpha$ and adjacent alkene protons of alkyl hydroperoxide group moved to higher fields after the addition of $\left[\mathrm{DiC}_{8}\right]_{2} \mathrm{MoO}_{4}$ (Figure 6). It is noteworthy that complex formation is rapid, while the generation of (+)-nootkatone is slower.

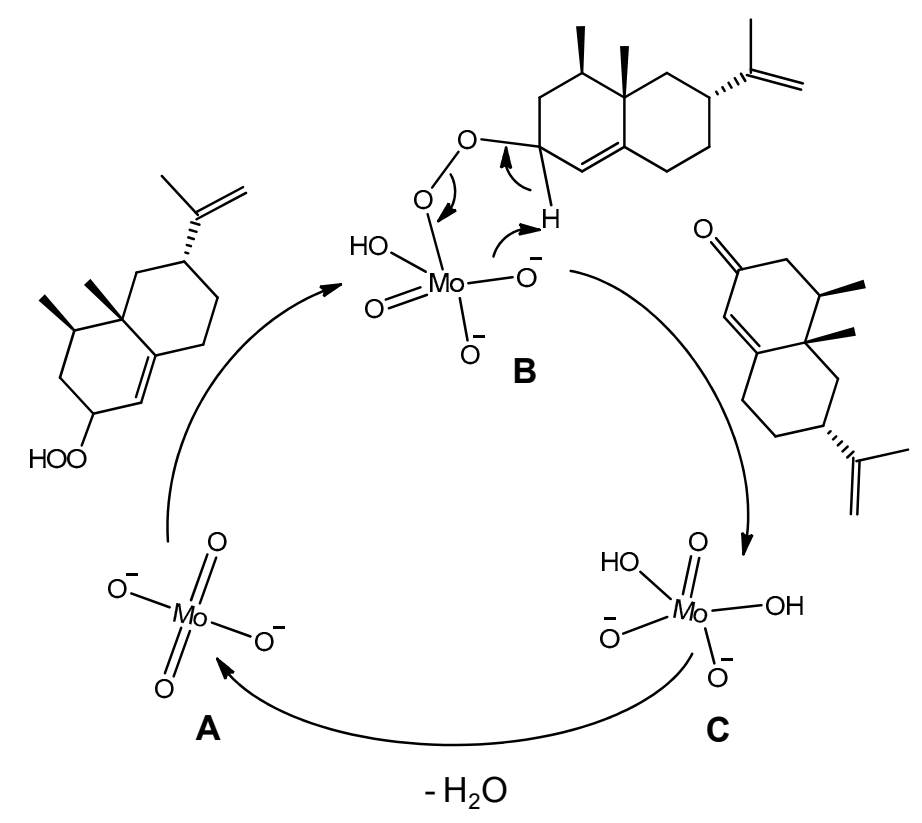

Figure 5. Proposed catalytic cycle for the $\left[\mathrm{DiC}_{8}\right]_{2} \mathrm{MoO}_{4}$-catalyzed dehydration of hydroperoxide 4 .<smiles>C=C(C)C1CCC2=CC(OO)C[C@H](C)[C@H]2C1</smiles>

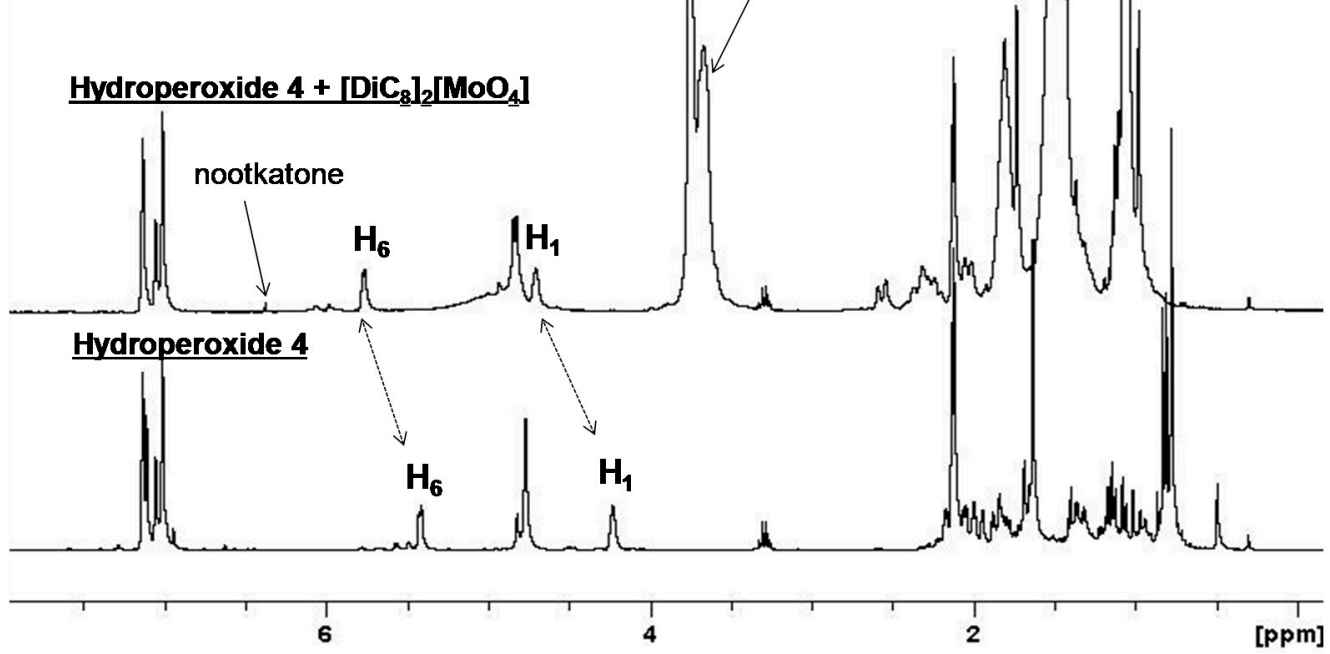

Figure 6. Evolution of the ${ }^{1} \mathrm{H}$ NMR spectrum of hydroperoxide 4 just after the addition of $\left[\mathrm{DiC}_{8}\right]_{2} \mathrm{MoO}_{4}$. 
Based on these findings, the one-pot cascade conversion of (+)-valencene into (+)-nootkatone was carried out in toluene in the presence of 0.2 equiv $\left[\mathrm{DiC}_{8}\right]_{2} \mathrm{MoO}_{4}$. Considering the low solubility of rose Bengal in toluene, 5,10,15,20-tetra-phenyl-21H,23H-porphine (TPP) was used as a photosensitizer. The photooxidation of $(+)$-valencene proceeded at room temperature and the conversion was complete in $5 \mathrm{~h}$. The solution was then heated at $50{ }^{\circ} \mathrm{C}$ for $4 \mathrm{~h}$ to complete the rearrangement and the dehydration steps leading to the desired nootkatone with an isolated yield of $40 \%$.

As far as the chemical process is concerned, molybdate ions are known to catalyze the disproportionation of hydrogen peroxide, a green and safe oxidant, into ${ }^{1} \mathrm{O}_{2}[51,52]$ with a quantitative yield of $100 \%$, affording a simple and safe alternative to the photochemical process.

The use of an amphiphilic catalyst, $\left[\mathrm{DiC}_{8}\right]_{2}\left[\mathrm{MoO}_{4}\right]$, was motivated by three main reasons:

1. the dark singlet oxygenation (i.e., the chemical oxidation versus the photooxidation [53]) of valencene can be efficiently performed in the absence of organic solvent thanks to the surface activity of the catalyst, which lowered the interfacial tension between the organic phase, i.e., the substrate, and the aqueous $\mathrm{H}_{2} \mathrm{O}_{2}$, thus generating nanodroplets and a higher interfacial area in the solvent-less medium;

2. $\left[\mathrm{DiC}_{8}\right]_{2}\left[\mathrm{MoO}_{4}\right]$ can play a dual catalytic role in Step 1 (see above) and Step 3 of the process;

3. it is a "balanced catalytic surfactant" that can thus provide a three-phase-microemulsion system (i.e., a microemulsion phase in equilibrium with both water and solvent excess phases) in the presence of water and an appropriate solvent, allowing for easy product isolation and catalyst recycling via simple phase separation [52].

During valencene peroxidation, $\mathrm{H}_{2} \mathrm{O}_{2}$ was added stepwise to favor the formation of the triperoxomolybdate $\left[\mathrm{MoO}\left(\mathrm{O}_{2}\right)_{3}\right]^{2-}$, the main precursor of ${ }^{1} \mathrm{O}_{2}$ [51]. The addition of $\mathrm{H}_{2} \mathrm{O}_{2}$ can be readily and visually controlled by the bleaching of the orange-red to pale yellow solution when $\mathrm{H}_{2} \mathrm{O}_{2}$ has been consumed (Figure 7). When conversion of (+)-valencene was completed, the mixture was incubated at $50{ }^{\circ} \mathrm{C}$ for $5 \mathrm{~h}$ providing nootkatone. Efficient separation of product and catalyst was easily achieved by addition of diethyl ether affording an optimal three-phase-microemulsion within a few seconds, avoiding the formation of undesired stable emulsions (Figure 7). This one-pot chemical process provided nootkatone with a yield of $46.5 \%$ in addition to some nootkatol (22\%). The nootkatol might have been formed through the direct interaction of some peroxomolybdate intermediates with valencene. Its formation can be minimized by a careful control of the $\mathrm{pH}$, which must be in the range 9-10 to favor the precursor of ${ }^{1} \mathrm{O}_{2}$, i.e., the triperoxomolybdate. At the end of the reaction, the products were simply isolated by removing the excess $\mathrm{Et}_{2} \mathrm{O}$ phase. The middle microemulsion phase contained the catalyst, $\left[\mathrm{DiC}_{8}\right]_{2} \mathrm{MoO}_{4}$, and some products (less than $20 \%$ ) that could be completely recovered after two extractions with diethyl ether. The middle phase microemulsion could be recycled without any loss of activity, since all the catalyst was contained in this phase and since the $\mathrm{H}_{2} \mathrm{O}_{2} / \mathrm{MoO}_{4}{ }^{2-}$ system is well known for not presenting leaching [52]. It is noteworthy that the reaction was even slightly kinetically superior with the recycling catalyst, probably due to a favorable preconditioning.

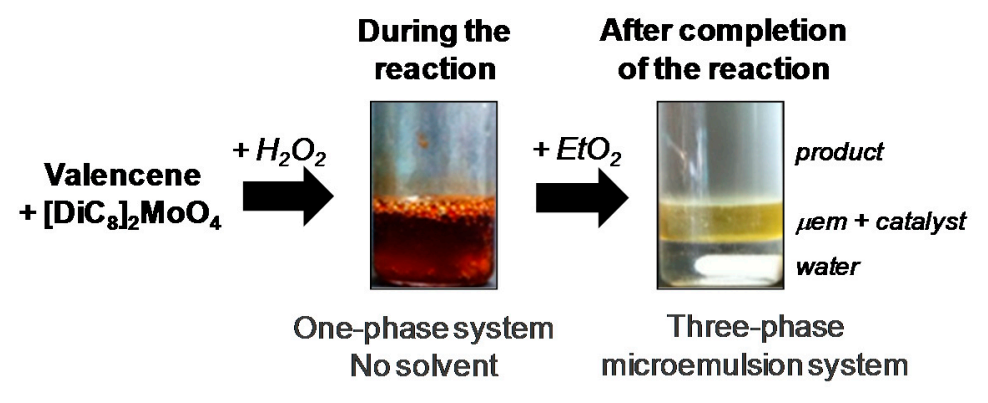

Figure 7. Dark ${ }^{1} \mathrm{O}_{2}$ oxygenation of (+)-valencene into (+)-nootkatone by the system $\left[\mathrm{DiC}_{8}\right]_{2} \mathrm{MoO}_{4} / \mathrm{H}_{2} \mathrm{O}_{2}$. 


\section{Materials and Methods}

\subsection{General Information}

Deuterium solvents were purchased from Eurisotop (Saint-Aubin, France) $(>99 \%)$. Rose Bengal (RB), tetraphenylporphyrin (TPP) and valencene were from Sigma-Aldrich (Saint-Quentin Fallavier, France) (99.9\%). Valencene was Sigma-Aldrich ${ }^{\circledR} S a i n t-Q u e n t i n$ Fallavier, France distilled in vacuum before use. The photooxidation was carried out with the sodium lamp Faeber Lighting System 150W ST (Uboldo, Italy) . Chemical shifts in NMR spectra were recorded in ppm $(\delta)$ relative to the internal standard tetramethylsilane (TMS). The signals were described as s (singlet), d (doublet), $t$ (triplet), $\mathrm{dd}$ (double doublet), $\mathrm{dt}$ (double triplet), $\mathrm{m}$ (multiplets), and br (broad).

\subsection{Photooxidation of (+)-Valencene $\mathbf{1}$ in Methanol with Rose Bengal as a Photosensitizer}

A $10 \mathrm{~mL} \mathrm{CH}_{3} \mathrm{OH}$ solution with $0.125 \mathrm{mg}$ of Rose Bengal was prepared in a $25 \mathrm{~mL}$ special flat flask for photooxidation. Valencene $(204.4 \mathrm{mg}, 1.0 \mathrm{mmol})$ was dissolved in the solution, and the reaction was then triggered by the bubbling of the oxygen under the light of the sodium lamp Faeber Lighting System $150 \mathrm{~W} \mathrm{ST}$ at $10^{\circ} \mathrm{C}$. The reaction was followed by NMR analysis (Bruker, Wissembourg, France) of the reaction mixture every $2 \mathrm{~h}$ until the conversion was complete. At the end of the reaction, the solvent was evaporated in vacuum, and the crude product was purified through chromatography on silica gel (petroleum ether/ethyl ether $=4: 1$ ). It is noteworthy that hydroperoxides 2,3 , and 4 can be separated by a tedious chromatography with an Rf equal to $0.5,0.4$, and 0.34 , respectively, but some hydroperoxide 2 rearrange into hydroperoxide 4 during the evaporation of the solvent, giving back a mixture of $\mathbf{2}$ and $\mathbf{4}$. A more rapid chromatography without separation of $\mathbf{2}$ and $\mathbf{3}$ minimizes the formation of $\mathbf{4}$, affording a mixture of $\mathbf{2}$ and $\mathbf{3}$ as major isomers with an 82:18 ratio. Thus, the desired product 2 was obtained with a yield of $41 \% .{ }^{1} \mathrm{H}$ NMR $\left(300 \mathrm{MHz}, \mathrm{CD}_{3} \mathrm{OD}\right) \delta=5.83(\mathrm{dt}, J=3.1 \mathrm{~Hz}$, $9.9 \mathrm{~Hz}, 1 \mathrm{H}), 5.61(\mathrm{~d}, J=9.9 \mathrm{~Hz}, 1 \mathrm{H}), 4.71-4.77(\mathrm{~m}, 1 \mathrm{H}), 4.66-4.70(\mathrm{~m}, 1 \mathrm{H}), 2.09-2.34(\mathrm{~m}, 4 \mathrm{H}), 1.74-1.82$ $(\mathrm{m}, 5 \mathrm{H}), 1.38-1.64(\mathrm{~m}, 4 \mathrm{H}), 0.89(\mathrm{~s}, 3 \mathrm{H}), 0.80(\mathrm{~d}, J=6.7 \mathrm{~Hz}, 3 \mathrm{H}) ;{ }^{13} \mathrm{C} \mathrm{NMR}\left(75 \mathrm{MHz}, \mathrm{CD}_{3} \mathrm{OD}\right) \delta=131.0$, 130.5, 107.6, 39.7, 35.4, 32.9, 30.7, 26.9, 25.2, 19.4, 13.9, 13.3. HRMS: calcd for $\mathrm{C}_{15} \mathrm{H}_{24} \mathrm{O}_{2}(\mathrm{M}+\mathrm{H})^{+}$ 237.3578, found 237.1849.

\subsection{Conversion of Hydroperoxide $\mathbf{2}$ into Hydroperoxide $\mathbf{4}$ via Schenck Rearrangement and Further Catalytic Conversion into (+)-Nootkatone 5}

Hydroperoxide 2 ( $42 \mathrm{mg}, 0.18 \mathrm{mmol}$ ) was dissolved in $1 \mathrm{~mL}$ of toluene- $d_{8}$ (for direct NMR analysis) and incubated at $40{ }^{\circ} \mathrm{C}$ for $5 \mathrm{~h}$, leading to the complete and quantitative conversion into $4 .{ }^{1} \mathrm{H}$ NMR $\left(300 \mathrm{MHz}\right.$, toluene- $\left.d_{8}\right) \delta=5.40-5.43(\mathrm{~m}, 1 \mathrm{H}), 4.74-4.77(\mathrm{~m}, 2 \mathrm{H}), 4.20-4.24(\mathrm{~m}, 1 \mathrm{H}), 1.78-2.18(\mathrm{~m}, 5 \mathrm{H})$, 1.60-1.68 (m, 4H), 1.30-1.41 (m, 2H), 0.94-1.19 (m, 2H), $0.82(\mathrm{~d}, J=6.9 \mathrm{~Hz}, 3 \mathrm{H}), 0.78(\mathrm{~s}, 3 \mathrm{H}) ;{ }^{13} \mathrm{C} \mathrm{NMR}$ (75 MHz, toluene- $\left.d_{8}\right) \delta=137.1,116.8,108.7,77.6,44.4,40.6,35.0,32.6,32.5,30.9,20.4,16.6,14.8$. HRMS: calcd for $\mathrm{C}_{15} \mathrm{H}_{24} \mathrm{O}_{2}(\mathrm{M}+\mathrm{H})^{+} 237.3578$, found 237.1849.

Then, $\left[\mathrm{DiC}_{8}\right]_{2} \mathrm{MoO}_{4}(24.9 \mathrm{mg}, 0.036 \mathrm{mmol})$ was dissolved in the reaction mixture as a catalyst to convert hydroperoxide 4 into nootkatone 5 . The mixture was incubated at $50{ }^{\circ} \mathrm{C}$ for $7.5 \mathrm{~h}$. When the conversion was complete, the solvent was evaporated in vacuum, and the reaction residue was subject to chromatography on silica gel (PE/ethyl ether $=3: 1$ ), affording $29.0 \mathrm{mg}$ of (+)-nootkatone as a colorless oil with a grapefruit flavor $(75 \%) .{ }^{1} \mathrm{H}$ NMR $\left(300 \mathrm{MHz}\right.$, toluene- $\left.d_{8}\right) \delta=5.74(\mathrm{~s}, 1 \mathrm{H}), 4.75-4.79$ $(\mathrm{m}, 1 \mathrm{H}), 4.70-4.73(\mathrm{~m}, 1 \mathrm{H}), 1.87-2.14(\mathrm{~m}, 5 \mathrm{H}), 1.67-1.73(\mathrm{~m}, 1 \mathrm{H}), 1.54-1.61(\mathrm{~m}, 5 \mathrm{H}), 0.97-1.12(\mathrm{~m}, 1 \mathrm{H})$, $0.79-0.87(\mathrm{~m}, 1 \mathrm{H}), 0.70(\mathrm{~s}, 3 \mathrm{H}), 0.59(\mathrm{~d}, J=6.9 \mathrm{~Hz}, 3 \mathrm{H}) ;{ }^{13} \mathrm{C}$ NMR $\left(75 \mathrm{MHz}\right.$, toluene- $\left.d_{8}\right) \delta=137.1,125.0$, 109.3, 43.8, 41.9, 40.2, 40.1, 32.4, 31.5, 20.4, 16.1, 14.4. HRMS: calcd for $\mathrm{C}_{15} \mathrm{H}_{22} \mathrm{O}(\mathrm{M}+\mathrm{H})^{+} 219.1749$, found 219.1748 .

3.4. Direct Synthesis of (+)-Nootkatone 5 in Toluene by Photooxidation of (+)-Valencene 1 in the Presence of $\left[\mathrm{DiC}_{8}\right]_{2} \mathrm{MoO}_{4}$

(+)-Valencene (202.4 mg, $1.0 \mathrm{mmol})$ and $\left[\mathrm{DiC}_{8}\right]_{2} \mathrm{MoO}_{4}(140.2 \mathrm{mg}, 0.2 \mathrm{mmol})$ were dissolved into $5.0 \mathrm{~mL}$ of toluene- $d_{8}$ containing $0.5 \mathrm{mg}$ of TPP. The solution was bubbled with oxygen and irradiated 
with a sodium lamp. The conversion of (+)-valencene was followed directly by ${ }^{1} \mathrm{H}$ NMR and was complete after $18 \mathrm{~h}$ at room temperature. Then, the solution was kept at $50^{\circ} \mathrm{C}$ for $4 \mathrm{~h}$ to achieve the (+)-nootkatone formation as confirmed by ${ }^{1} \mathrm{H}$ NMR. The product was isolated by chromatography on silica gel (PE/ethyl ether $=3: 1)$, and $75.6 \mathrm{mg}$ of pure nootkatone was isolated $(40 \%)$.

\subsection{Dark Singlet Oxygenation of (+)-Valencene 1 to (+)-Nootkatone $\mathbf{5}$}

$\left[\mathrm{DiC}_{8}\right]_{2} \mathrm{MoO}_{4}(175 \mathrm{mg}, 0.25 \mathrm{mmol})$, valencene (102.2 mg, $\left.0.5 \mathrm{mmol}\right), \mathrm{H}_{2} \mathrm{O}_{2}(58 \mu \mathrm{L}$ of a $50 \mathrm{wt} . \%$ solution, $1.0 \mathrm{mmol}$ ), and $30 \mu \mathrm{L}$ of $\mathrm{NH}_{3}$ aqueous solution were introduced into a glass tube. The reaction mixture was stirred and kept at $30{ }^{\circ} \mathrm{C}$. Another batch of $\mathrm{H}_{2} \mathrm{O}_{2}(58 \mu \mathrm{L}$ of a $50 \mathrm{wt}$. \% solution, $1.0 \mathrm{mmol}$ ) was added when the red color faded. A total of 15 batches, i.e., $0.87 \mathrm{~mL}$ of $\mathrm{H}_{2} \mathrm{O}_{2} 50$ wt. \%, $15 \mathrm{mmol}$, to complete the conversion of (+)-valencene. Then, the reaction mixture was incubated at $50{ }^{\circ} \mathrm{C}$ for several hours for the complete formation of nootkatone. The solution was cooled down to room temperature, and $2 \mathrm{~mL}$ of diethyl ether were added. A three-phase microemulsion system was spontaneously formed. The upper organic phase was separated and the middle phase microemulsion was extracted two more times $(2 \mathrm{~mL} \times 2)$. The organic phases were combined and evaporated. The residue was subject to the chromatography on silica gel (PE/ethyl ether = 3:1), affording $43 \mathrm{mg}$ of the desired nootkatone (39\%). The spectra were in agreement with those previously reported.

\subsection{Preparative Scale Synthesis of (+)-Nootkatone 5}

$\left[\mathrm{DiC}_{8}\right]_{2} \mathrm{MoO}_{4}(876 \mathrm{mg}, 1.25 \mathrm{mmol})$, valencene (510 mg, $\left.2.5 \mathrm{mmol}\right), \mathrm{H}_{2} \mathrm{O}_{2}(290 \mu \mathrm{L}$ of a 50 wt. \% solution, $5 \mathrm{mmol}$ ), and $150 \mu \mathrm{L}$ of an $\mathrm{NH}_{3}$ aqueous solution were introduced into a glass tube. The reaction mixture was stirred and kept at $30{ }^{\circ} \mathrm{C}$. Another batch of $\mathrm{H}_{2} \mathrm{O}_{2}(290 \mu \mathrm{L}$ of a $50 \mathrm{wt}$. \% solution, $1.0 \mathrm{mmol}$ ) was added when the red color faded. A total of 15 batches, i.e., $4.35 \mathrm{~mL}$ of $\mathrm{H}_{2} \mathrm{O}_{2}$ $50 \mathrm{wt}$. \%, $75 \mathrm{mmol}$, to complete the conversion of (+)-valencene. Then, the reaction mixture was incubated at $50{ }^{\circ} \mathrm{C}$ overnight for the complete formation of nootkatone. The solution was cooled down to room temperature, and $6 \mathrm{~mL}$ of diethyl ether were added. The three-phase microemulsion system was spontaneously obtained. The organic phase was separated, and the middle phase microemulsion was extracted two more times $(6 \mathrm{~mL} \times 2)$. The organic phases were combined and evaporated. The yield of isolated (+)-nootkatone was $46.5 \%$.

\section{Conclusions}

One-pot catalytic synthesis of (+)-nootkatone via singlet oxygenation of (+)-valencene was successfully performed with the possibility of generating ${ }^{1} \mathrm{O}_{2}$ either photochemically or chemically. In the chemical process, molybdate plays a dual catalytic role as it disproportionates $\mathrm{H}_{2} \mathrm{O}_{2}$ into ${ }^{1} \mathrm{O}_{2}$ and converts the hydroperoxide arising from the Schenck rearrangement into the desired nootkatone. This latter reaction has not been reported before for the conversion of allylic hydroperoxides into unsaturated ketones. The process reported here with (+)-nootkatone, obtained in relatively high yields compared to previous reported work, is promising, as it opens new avenues for other allylic hydroperoxides and further green industrial developments.

Supplementary Materials: The following are available online at www.mdpi.com/2073-4344/6/12/184/s1.

Acknowledgments: The ANR (Catasurf Project ANR-10-CD2I-01) is acknowledged for the PhD fellowship of Bing Hong and financial supports. Chevreul Institute (FR 2638), Ministère de l'Enseignement Supérieur et de la Recherche, Région Hauts-de-France, and FEDER are acknowledged for supporting and funding partially this work.

Author Contributions: B.H. and R.L. performed all the experiments, except some NMR spectra, which were carried out and analyzed by S.D.; P.L.A. contributed his expertise on valencene oxidation and nootkatone synthesis; V.N.-R. was the leader of the project.

Conflicts of Interest: The authors declare no conflict of interest. 


\section{References}

1. Erdtman, H.; Hirose, Y. The chemistry of the natural order cupressales. Xlvi. The structure of nootkatone. Acta Chem. Scand. 1962, 16, 1311-1314. [CrossRef]

2. MacLeod, W.D., Jr.; Buigues, N.M. Sesquiterpenes. I. Nootkatone, a new grapefruit flavor constituent. J. Food Sci. 1964, 29, 565-568. [CrossRef]

3. Haring, H.G.; Rijkens, F.; Boelens, H.; Van der Gen, A. Olfactory studies on enantiomeric eremophilane sesquiterpenoids. J. Agric. Food Chem. 1972, 20, 1018-1021. [CrossRef]

4. EFSA Panel on Additives and Products or Substances used in Animal Feed (FEEDAP). Safety and efficacy of secondary alicyclic saturated and unsaturated alcohols, ketones, ketals and esters with ketals containing alicyclic alcohols or ketones and esters containing secondary alicyclic alcohols from chemical group 8 when used as flavourings for all animal species. EFSA J. 2016, 14, 44-75.

5. Zhu, B.C.R.; Henderson, G.; Sauer, A.M.; Yu, Y.; Crowe, W.; Laine, R.A. Structure-activity of valencenoid derivatives and their repellence to the formosan subterranean termite. J. Chem. Ecol. 2003, 29, 2695-2701. [CrossRef] [PubMed]

6. Panella, N.A.; Dolan, M.C.; Karchesy, J.J.; Xiong, Y.; Peralta-Cruz, J.; Khasawneh, M.; Montenieri, J.A.; Maupin, G.O. Use of novel compounds for pest control: Insecticidal and acaricidal activity of essential oil components from heartwood of alaska yellow cedar. J. Med. Entomol. 2005, 42, 352-358. [CrossRef] [PubMed]

7. Leitereg, T.J. Synthesis of sesquiterpenoids related to nootkatone. Structure determination by nmr using tris(dipivalomethanato)europium. Tetrahedron Lett. 1972, 13, 2617-2620. [CrossRef]

8. Pesaro, M.; Bozzato, G.; Schudel, P. The total synthesis of racemic nootkatone. Chem. Commun. 1968, 1152-1154. [CrossRef]

9. Odom, H.C.; Pinder, A.R. Total synthesis of ( \pm )-nootkatone. Chem. Commun. 1969, 26-27. [CrossRef]

10. Marshall, J.A.; Ruden, R.A. Stereoselective total synthesis of racemic nootkatone. J. Org. Chem. 1971, 36, 594-596. [CrossRef]

11. McGuire, H.M.; Odom, H.C., Jr.; Pinder, A.R. Further synthetic studies in the nootkatane sesquiterpene group. New total synthesis of $( \pm)$-valencene and $( \pm)$-nootkatone. J. Chem. Soc. Perkin Trans. 1 1974, 1879-1883. [CrossRef]

12. Dastur, K.P. Stereoselective approach to eremophilane sesquiterpenes. Synthesis of $( \pm)$-nootkatone and ( \pm )- $\alpha$-vetivone. J. Am. Chem. Soc. 1974, 96, 2605-2608. [CrossRef]

13. Naf, F.; Decorzant, R.; Thommen, W. A novel entry to the eremophilane and valencane sesquiterpenes via a stereoselective intramolecular diels-alder reaction. Helv. Chim. Acta 1979, 62, 114-118. [CrossRef]

14. Hiyama, T.; Shinoda, M.; Nozaki, H. A new stereoselective synthesis of $( \pm)$-nootkatone by means of cyclopentenone annulation. Tetrahedron Lett. 1979, 20, 3529-3532. [CrossRef]

15. Majetich, G.; Behnke, M.; Hull, K. A stereoselective synthesis of $( \pm)$-nootkatone and $( \pm)$-valencene via an intramolecular sakurai reaction. J. Org. Chem. 1985, 50, 3615-3618. [CrossRef]

16. Handore, K.L.; Seetharamsingh, B.; Reddy, D.S. Ready access to functionally embellished cis-hydrindanes and cis-decalins: Protecting group-free total syntheses of $( \pm)$-nootkatone and $( \pm)$-noreremophilane. J. Org. Chem. 2013, 78, 8149-8154. [CrossRef] [PubMed]

17. Yanami, T.; Miyashita, M.; Yoshikoshi, A. Stereocontrolled synthesis of (+)-nootkatone from (-)- $\beta$-pinene. J. Chem. Soc. Chem. Commun. 1979, 525-527. [CrossRef]

18. Yanami, T.; Miyashita, M.; Yoshikoshi, A. Synthetic study of (+)-nootkatone from (-)- $\beta$-pinene. J. Org. Chem. 1980, 45, 607-612. [CrossRef]

19. Sauer, A.M.; Crowe, W.E.; Henderson, G.; Laine, R.A. An efficient and economic asymmetric synthesis of (+)-nootkatone, tetrahydronootkatone, and derivatives. Org. Lett. 2009, 11, 3530-3533. [CrossRef] [PubMed]

20. Chappell, J.; Greenhagen, B. Plant Sesquiterpene Synthase Cdna, Production with Recombinant Organisms of the Enzyme, and Its Use for Production of Sesquiterpenes. U.S. Patent 20060218661A1, 28 September 2006.

21. Hunter, G.L.K.; Brogden, W.B., Jr. Conversion of valencene to nootkatone. J. Food Sci. 1965, 30, 876-878. [CrossRef]

22. Shaffer, G.W.; Eschinasi, E.H.; Purzycki, K.L.; Doerr, A.B. Oxidations of valencene. J. Org. Chem. 1975, 40, 2181-2185. [CrossRef]

23. Wilson, C.W., III; Shaw, P.E. Synthesis of nootkatone from valencene. J. Agric. Food Chem. 1978, 26, 1430-1432. [CrossRef] 
24. Salvador, J.A.R.; Clark, J.H. The allylic oxidation of unsaturated steroids by tert-butyl hydroperoxide using surface functionalised silica supported metal catalysts. Green Chem. 2002, 4, 352-356. [CrossRef]

25. Silvestre, S.M.; Salvador, J.A.R. Allylic and benzylic oxidation reactions with sodium chlorite. Tetrahedron 2007, 63, 2439-2445. [CrossRef]

26. Garcia-Cabeza, A.L.; Marin-Barrios, R.; Moreno-Dorado, F.J.; Ortega, M.J.; Massanet, G.M.; Guerra, F.M. Allylic oxidation of alkenes catalyzed by a copper-aluminum mixed oxide. Org. Lett. 2014, 16, 1598-1601. [CrossRef] [PubMed]

27. Girhard, M.; Machida, K.; Itoh, M.; Schmid, R.D.; Arisawa, A.; Urlacher, V.B. Regioselective biooxidation of (+)-valencene by recombinant E. coli expressing CYP109B1 from Bacillus subtilis in a two-liquid-phase system. Microb. Cell Fact. 2009, 8, 1-12. [CrossRef] [PubMed]

28. Sakamaki, H.; Itoh, K.-i.; Taniai, T.; Kitanaka, S.; Takagi, Y.; Chai, W.; Horiuchi, C.A. Biotransformation of valencene by cultured cells of Gynostemma pentaphyllum. J. Mol. Catal. B Enzym. 2005, 32, 103-106. [CrossRef]

29. Furusawa, M.; Hashimoto, T.; Noma, Y.; Asakawa, Y. Highly efficient production of nootkatone, the grapefruit aroma from valencene, by biotransformation. Chem. Pharm. Bull. 2005, 53, 1513-1514. [CrossRef] [PubMed]

30. Krügener, S.; Krings, U.; Zorn, H.; Berger, R.G. A dioxygenase of Pleurotus sapidus transforms (+)-valencene regio-specifically to (+)-nootkatone via a stereo-specific allylic hydroperoxidation. Bioresour. Technol. 2010, 101, 457-462. [CrossRef] [PubMed]

31. Rickert, A.; Krombach, V.; Hamers, O.; Zorn, H.; Maison, W. Enzymatic allylic oxidations with a lyophilisate of the edible fungus Pleurotus sapidus. Green Chem. 2012, 14, 639-644. [CrossRef]

32. Kaspera, R.; Krings, U.; Nanzad, T.; Berger, R.G. Bioconversion of (+)-valencene in submerged cultures of the ascomycete Chaetomium globosum. Appl. Microbiol. Biotechnol. 2005, 67, 477-483. [CrossRef] [PubMed]

33. Sowden, R.J.; Yasmin, S.; Rees, N.H.; Bell, S.G.; Wong, L.-L. Biotransformation of the sesquiterpene (+)-valencene by cytochrome p450 $\mathrm{cam}$ and $\mathrm{p} 450_{\mathrm{BM}-3}$. Org. Biomol. Chem. 2005, 3, 57-64. [CrossRef] [PubMed]

34. Cankar, K.; van Houwelingen, A.; Bosch, D.; Sonke, T.; Bouwmeester, H.; Beekwilder, J. A chicory cytochrome p450 mono-oxygenase cyp71av8 for the oxidation of (+)-valencene. FEBS Lett. 2011, 585, 178-182. [CrossRef] [PubMed]

35. Fraatz, M.A.; Berger, R.G.; Zorn, H. Nootkatone-A biotechnological challenge. Appl. Microbiol. Biotechnol. 2009, 83, 35-41. [CrossRef] [PubMed]

36. Kitayama, K.; Tatsumi, A.; Terada, M.; Hirai, N. Process for Producing Organic Compounds by Catalysis of Imide Compounds. EP1164131A1, 19 December 2001.

37. Huang, R.; Christenson, P.A.; Labuda, I.M. Process for the Preparation of Nootkatone by Laccase Catalysis. U.S. Patent 6200786B1, 13 March 2001.

38. Davies, A.G.; Davison, I.G.E. Rearrangements of allylic hydroperoxides derived from (+)-valencene. J. Chem. Soc. Perkin Trans. 2 1989, 825-830. [CrossRef]

39. Ohloff, G. Singlet oxygen: A reagent in organic synthesis. Pure Appl. Chem. 1975, 43, 481-502. [CrossRef]

40. Davies, A.G. The schenck rearrangement of allylic hydroperoxides. J. Chem. Res. 2009, 2009, 533-544. [CrossRef]

41. Neuenschwander, U.; Jensen, K.F. Olefin autoxidation in flow. Ind. Eng. Chem. Res. 2014, 53, 601-608. [CrossRef]

42. Avila, D.V.; Davies, A.G.; Davison, I.G.E. Stereoselectivity in the formation and allylic rearrangement of 8a-methyl- and 8a-ethyl-1,2,3,4,4a,7,8,8a-octahydronaphthalenyl hydroperoxides. J. Chem. Soc. Perkin Trans. 2 1988, 1847-1852. [CrossRef]

43. Ponce, M.A.; Ramirez, J.A.; Galagovsky, L.R.; Gros, E.G.; Erra-Balsells, R. Singlet-oxygen ene reaction with 3[small beta]-substituted stigmastanes. An alternative pathway for the classical schenck rearrangement. J. Chem. Soc. Perkin Trans. 2 2000, 2351-2358. [CrossRef]

44. Porter, N.A.; Mills, K.A.; Caldwell, S.E.; Dubay, G.R. The mechanism of the [3,2] allylperoxyl rearrangement: A radical-dioxygen pair reaction that proceeds with stereochemical memory. J. Am. Chem. Soc. 1994, 116, 6697-6705. [CrossRef]

45. Brill, W.F. The isolation and rearrangement of pure acyclic allylic hydroperoxides. J. Am. Chem. Soc. 1965, 87, 3286-3287. [CrossRef] 
46. Beckwith, A.L.J.; Davies, A.G.; Davison, I.G.E.; Maccoll, A.; Mruzek, M.H. The mechanisms of the rearrangements of allylic hydroperoxides: 5[small alpha]-hydroperoxy-3[small beta]-hydroxycholest-6-ene and 7[small alpha]-hydroperoxy-3[small beta]-hydroxycholest-5-ene. J. Chem. Soc. Perkin Trans. 2 1989, 815-824. [CrossRef]

47. Partenheimer, $\mathrm{W}$. The effect of zirconium in metal/bromide catalysts during the autoxidation of p-xylene: Part i. Activation and changes in benzaldehyde intermediate formation. J. Mol. Catal. A Chem. 2003, 206, 105-119. [CrossRef]

48. Landheer, I.; Ginsburg, D. Propellanes-LIII. Tetrahedron 1981, 37, 143-150. [CrossRef]

49. Schenck, G.O.; Neumuller, O.A.; Eisfeld, W. Photosensitive autoxidation of steroids. Ii. New type of allyl rearrangement of steroid hydroperoxides. Angew. Chem. 1958, 70, 595. [CrossRef]

50. Sato, K.; Aoki, M.; Takagi, J.; Zimmermann, K.; Noyori, R. A practical method for alcohol oxidation with aqueous hydrogen peroxide under organic solvent- and halide-free conditions. Bull. Chem. Soc. Jpn. 1999, 72, 2287-2306. [CrossRef]

51. Nardello, V.; Marko, J.; Vermeersch, G.; Aubry, J.M. 90mo nmr and kinetic studies of peroxomolybdic intermediates involved in the catalytic disproportionation of hydrogen peroxide by molybdate ions. Inorg. Chem. 1995, 34, 4950-4957. [CrossRef]

52. Nardello-Rataj, V.; Caron, L.; Borde, C.; Aubry, J.-M. Oxidation in three-liquid-phase microemulsion systems using "balanced catalytic surfactants". J. Am. Chem. Soc. 2008, 130, 14914-14915. [CrossRef] [PubMed]

53. Alsters, P.L.; Jary, W.; Nardello-Rataj, V.; Aubry, J.-M. "Dark" singlet oxygenation of $\beta$-citronellol: A key step in the manufacture of rose oxide. Org. Process. Res. Dev. 2010, 14, 259-262. [CrossRef]

(C) 2016 by the authors; licensee MDPI, Basel, Switzerland. This article is an open access article distributed under the terms and conditions of the Creative Commons Attribution (CC-BY) license (http:/ / creativecommons.org/licenses/by/4.0/). 